Bond University

Research Repository

\title{
Counter-terrorism with Chinese characteristics
}

\author{
Dellios, Rosita
}

Published in:

Handbook of Terrorism and Counter Terrorism Post 9/11

DOI:

$10.4337 / 9781786438027.00037$

Licence:

Other

Link to output in Bond University research repository.

Recommended citation(APA):

Dellios, R. (2019). Counter-terrorism with Chinese characteristics. In D. M. Jones, P. Schulte, C. Ungerer, \& M.

L. R. Smith (Eds.), Handbook of Terrorism and Counter Terrorism Post 9/11 (pp. 340-350). Edward Elgar

Publishing. https://doi.org/10.4337/9781786438027.00037

\section{General rights}

Copyright and moral rights for the publications made accessible in the public portal are retained by the authors and/or other copyright owners and it is a condition of accessing publications that users recognise and abide by the legal requirements associated with these rights.

For more information, or if you believe that this document breaches copyright, please contact the Bond University research repository coordinator. 


\title{
Counter-Terrorism with Chinese Characteristics
}

\author{
Rosita Dellios, Bond University
}

Counter-terrorism in the People's Republic of China (PRC, China) is largely a domestic affair aimed at non-Han ethnic groups who challenge the status quo through acts of political resistance, including bombings and self-immolation. China's population of 1.3 billion comprises 56 ethnic groups, the largest at $91.6 \%$ being Han. Yet $60 \%$ of China's territory is populated by non-Han minorities. They are mostly the Turkic-speaking people in the northwest and Tibetans in China's far west. It is here in these remote but strategically important areas of China that terrorism takes on its 'Chinese characteristics', that is, the threat of secession and its manifold implications. With China's global interests spreading, especially via the Belt and Road Initiative (BRI) by which China is emerging as a major transregional power, counter-terrorism efforts are also projected beyond the PRC's borders. In both domestic and international efforts to combat terrorism, China has taken a determined stance, comprehensively employing military, paramilitary, political, technological, and regional security measures. This chapter examines the perceived threat, the response, and its efficacy - all within the wider lens of China's own experience and a security doctrine that sees political dissent as insipient terrorism.

\section{China's Muslim Population}

China's Muslim population stands at 22 million and is made up of various groups, including Han Chinese Muslims (Hui) whose ancestors had arrived through the old silk roads of trade and also during the Mongol invasion in the 13th century. This was when China became a khanate of the Mongol Empire and was ruled as the Yuan Dynasty (1279-1368). Being culturally Chinese and having assimilated long ago, Hui are less of a terrorist concern for the authorities. Indeed, they are a potential diplomatic asset as China expands its influence along the new silk roads or BRI where in many places Islamic culture prevails. China can present itself as a multicultural civilisation with historic links to Islam. More problematic for the state is the Turkic-speaking Uyghur (also transliterated as 'Uighur'). They form the largest Muslim group, and along with smaller groups such as those of Kazakh, Kyrgyz, Uzbek, and Tajik ethnicities, live in Xinjiang Uyghur Autonomous Region (XUAR). This Central Asian corner of China shares borders with Kazakhstan, Kyrgyzstan, Tajikistan, Mongolia, Russia, India, Pakistan, and Afghanistan.

The name Xinjiang means 'new frontier', as it was acquired through conquest relatively recently in Chinese history. The Manchu rulers of China's last dynasty, the Qing, annexed it in the 18th century and again in the 19th century after a short period of independence from 
1867 to 1877 . Modern China has retained the old imperial borders. Xinjiang formed the eastern part of the vast Eurasia continent, sometimes referred to as Turkistan to denote an area where people of Turkic linguistic background were found. It has since taken on political connotations. The name 'East Turkistan' has been used by separatist groups, including the terrorist-designated 'East Turkistan Islamic Movement' (ETIM). Besides the decade of independence in the 19th century, two other instances of brief statehood may be found in the Turkish Islamic Republic of East Turkistan (TIRET) which lasted from 1933 to 1934 and was supported by Britain; and the East Turkistan Republic (ETR) of 1944 to 1949, backed by the Soviet Union. Since then, as an 'autonomous region' Xinjiang, like Tibet and other ethnic minority provinces, is theoretically enjoying a degree of self-rule. However, the administrative designation of 'autonomous' sits uneasily with policies which in the West are commonly condemned as having turned Xinjiang into a gulag or vast provincial prison. How has this come about?

\section{Re-education Camps and De-radicalisation}

China has attempted to assimilate the Muslims it suspects to be jihadists through 'deradicalisation'. The lineage of this method goes back to the 're-education through labour' model used in Maoist China and which was officially ended as late as 2013. However, since 2017 reports emerged of possibly a million Muslims in Xinjiang - about 10 percent of the adult Muslim population - being interned in clandestine re-education camps in which "detainees can be held indefinitely without process or recourse". ${ }^{1}$ According to sources, as reported by Human Rights Watch, the re-education entails "people being obliged to sit for hours at a time and listen to lectures about the merits of Xi Jinping thought, for example". 2 When the UN Committee on the Elimination of Racial Discrimination expressed its concerns over the internments at a UN meeting in Geneva in 2018, the Chinese response was that "Xinjiang citizens, including the Uighurs, enjoy equal freedom and rights" but that reeducation programs did exist as a counter to extremism. ${ }^{3}$ The state-run Global Times newspaper said security measures in Xinjiang prevented it from turning into "China's Syria" or "China's Libya", adding that these were interim measures:

Xinjiang is at a special stage of development where there is no room for destructive Western public opinions. Peace and stability must come above all else. With this as the goal, all measures can be tried. We must hold onto our belief that keeping turmoil away from Xinjiang is the greatest human right. ${ }^{4}$

\footnotetext{
${ }^{1}$ Zenz, Adrian, 'New Evidence for China's Political Re-Education Campaign in Xinjiang', China Brief 18, 10 (15 May 2018). Retrieved from https://jamestown.org/program/evidence-for-chinas-political-re-educationcampaign-in-xinjiang/

${ }^{2}$ Quoted in de Bourmont, Martin, 'China's Campaign against Uighur Diaspora Ramps Up', Foreign Policy, 3 April 2018. Retrieved from https://foreignpolicy.com/2018/04/03/chinas-campaign-against-uighur-diasporaramps-up/

3 'China Uighurs: Beijing Denies Detaining One Million', BBC News, 13 August 2018.

4 'Protecting Peace, Stability is Top of Human Rights Agenda for Xinjiang', Global Times, 12 August 2018.
} 
The assimilation process has been described as a form of "coercive social engineering" which is accompanied by advanced surveillance technology. The rest of China is not immune to the use of surveillance and big data to control the population, including "predictive policing", 5 but Xinjiang is considered to be at the forefront of such activity.

The assimilation sought is one which requires the shedding of old identities and the acquisition of a state-endorsed one:

In Xinjiang's contemporary camps it appears that Beijing wants internees to ultimately return to "normal" life cleansed of markers of Uyghur (and other Turkic-Muslims) distinctiveness and Otherness - such as language, religion, and cultural practice - it has come to perceive as an obstacle to the complete integration of the region. This intent is entirely consistent with President Xi Jinping's April 2014 call for Xinjiang residents of all ethnicities to identify themselves with China, the Chinese nation, its culture, and "socialism with Chinese characteristics". ${ }^{6}$

The Chinese state is not alone in attempting to assimilate Turkic Muslims. There has emerged a dialectic between the Chinese Communist Party (CCP) and Islamic State (IS) in which IS propaganda videos for recruiting Uyghurs promote a sense of inclusion, in contrast to China's exclusionist labelling. Rosenblatt, in discussing data on over 100 Uyghur 'fighters' (including an 80-year-old quoted below who sounds more like a refugee) with Islamic State, refers to the content of a promotional video:

"I was subjected to oppression [in Xinjiang] at the hands of the Chinese idolators," explains Muhammed Amin, the 80-year-old Uyghur fighter, referring to joining ISIS ("hijrah") the same way Muslims refer to the prophet Mohammed when he fled persecution in Mecca in 622 A.D. Later in the clip, Uyghur children in clean classrooms learn religion — forbidden in China —and spout anti-Chinese government slogans. ${ }^{7}$

Another reciprocal element is that both the Chinese state through its security forces and the jihadists employ fear in the pursuit of their objective. This is an attribute of terrorism, ${ }^{8}$ yet neither side views itself as the culprit. Instead, Beijing has introduced "new crimes of terrorism" to its criminal law, ${ }^{9}$ while the "Chinese idolators", as the quote from the IS video states, persecute Muslims. As to which side is achieving its ends, thus far the Chinese state

\footnotetext{
${ }^{5}$ International Institute for Strategic Studies, 'Big Brother Meets Big Data', Cyber Report, 2-8 March 2018.

${ }^{6}$ Clarke, Michael, 'Xinjiang's “Transformation Through Education” Camps', The Interpreter, 25 May 2018.

Retrieved from https://www.lowyinstitute.org/the-interpreter/xinjiangs-transformation-through-education-camps ${ }^{7}$ Rosenblatt, Nate, 'All Jihad is Local: What ISIS' Files Tell Us about Its Fighters', New America, July 2016 , p. 28.

${ }^{8}$ Smith, M.L.R. and Jones, David Martin, 'What Carl Might Have Said about Terrorism: How Strategic Theory can Enlighten an Essentially Contested Debate', Infinity Journal 6, 2 (summer 2018), pp. 30-35.

9 “The Supreme People's Procuratorate (SPP), the Supreme People's Court (SPC), the Ministry of Public Security and Ministry of Justice issued a document on practical standards for judges and prosecutors to identify new crimes of terrorism introduced by a revision to the Criminal Law in 2015, and regulate prosecuting procedures.” Xinhua, 'China Introduces Practical Rules to Convict Terrorists', Global Times, 16 June 2018. Retrieved from http://www.globaltimes.cn/content/1107194.shtml.
} 
has succeeded insofar as its sovereign borders are intact and Xinjiang has not become "China's Syria”. China cannot afford to lose Xinjiang. Its strategic importance derives not only from its natural resources (especially oil and gas) but its intercontinental links through the Belt and Road Initiative. It provides overland access to Gwadar port near the Persian Gulf and acts as a buffer against potential geopolitical rivalries and the spread of ethno-religious militancy. ${ }^{10}$

\section{China's Tibet Problem}

Another border region which has been susceptible to unrest is Tibet. Its relationship with China goes back centuries and has seen periods of Chinese suzerainty over this Buddhist polity as well as rebellion and independence. Shortly after the Chinese Communist Party came to power in China it absorbed Tibet, consolidating its western frontier. In 1959, after a failed rebellion by Tibetans against Chinese rule, Tibet's spiritual leader - the Dalai Lama fled across the mountains to India where his government-in-exile was given sanctuary. China saw this as a treacherous development and viewed India's intentions as being meddlesome. Whether India had acted out of humanitarian concern, the geopolitical imperative was much the same as it was for past imperial players in this region, be they Mongol, Chinese, British or Russian. Indeed, in the Anglo-Russian Entente of 1907, Britain and Russia had agreed to Tibet remaining a buffer zone between the two, with China as its suzerain overlord.

To this day, the old problems remain: the Tibet Autonomous Region lies across China's remaining land border disputes - those with India and Bhutan. The dispute with India, based on old British maps which Beijing did not recognise, had led to the 1962 Sino-Indian border war. China won this limited war and kept the western Himalayan sector where it had built a military road connecting Tibet with Xinjiang. Chinese forces withdrew from the eastern sector, but competing claims and occasional clashes have continued. Moreover, the Dalai Lama has remained a thorn in the side of Beijing, having kept alive the cause of Tibetan culture in international circles. Beijing considers him to be a "splittist" (a separatist hiding "under the cloak of religion") and discourages foreign leaders from meeting with him. Tibet is also valuable to China as a source of water. Dubbed a Third Pole (after the North and South Poles), Tibet is the source of rivers that flow from west to east across China, down into the Indian subcontinent and south into mainland Southeast Asia.

As can be seen, neither Xinjiang nor Tibet can easily secede from China. If they did, China would be reduced to its Ming Dynasty (1368-1644) borders of more fertile land in the east of the country. But the old Ming in modern China becomes as a 'rump state' without its traditional buffer zones, the source of its rivers in Tibet, resources, the new silk roads of trade and Central Asian energy pipelines. Above all, it would leave China perilously close to Muslim populations it had disenfranchised under Chinese rule, and a nationalist domestic public that could turn on the ruling Chinese Communist Party for losing more than half of China. As if this were not enough, the 'renegade province' of Taiwan would in all likelihood

\footnotetext{
${ }^{10}$ See Ferguson, R. James, China's Eurasian Dilemmas: Roads and Risks for a Sustainable Global Power (Cheltenham, UK: Edward Elgar, 2018).
} 
declare formal independence. China would then be hobbled strategically at sea - as Taiwan would represent a weak link in the first island chain of China's maritime defence (spanning Japan and archipelagic Southeast Asia) - in addition to its overland exposure. If Beijing had no enemies, or was surrounded by allies, this might not be an immediate concern. As matters stand, China's self-identified 'strategic competitor', ${ }^{11}$ the United States, casts a shadow over the Chinese political order and sovereign claims. This, then, is China's strategic context for identifying 'terrorism'. Its day-to-day reality has been to deter acts of terrorism through crackdowns ('Strike Hard' campaigns') and societal controls but such measures may well have been counter-productive, alienating the very people China has sought to call its own.

In the decade prior to 2001, China reported that "over 200 terrorist incidents in Xinjiang" had resulted in "the deaths of 162 people of all ethnic groups". ${ }^{12}$ Ethnic Uyghurs and Kazakhs in Xinjiang experienced hash crackdowns in 1990 and 1997, but these were kept quiet, compared to the 2009 riots in which nearly 200 people were killed. Some 20,000 troops (both People's Armed Police and People's Liberation Army) were deployed at Xinjiang's capital city of Urumqi after Uyghur riots broke out in July 2009, and 130,000 were reportedly deployed throughout region. Phone and internet restrictions were imposed after the crackdown to cut off Xinjiang from the outside world and hence its ability to organise rebellion. As the repression mounted, more than 10,000 Uyghurs fled China, according to Uyghur exiles.

In 2013 and 2014, there were attacks outside of Xinjiang. The first was in Beijing's Tiananmen Square (five died); and the second at Kunming railway station in Yunnan Province in southwestern China (29 deaths). ${ }^{13}$ Since then, there has been a sharp decline in terrorist acts in China "both in terms of frequency and intensity, except for very few highprofile attacks". ${ }^{14}$

China has shown equal determination to keep Tibet under firm control, as evidenced in its Tiananmen-style crackdown of a Tibetan uprising in 2008. Since then, the government has controlled the monasteries, imprisoned those with dissenting views, and effectively curtailed religious freedom. Protests even took the form of self-immolation by monks and nuns. Since 2009, 153 Tibetans have engaged in self-immolation. ${ }^{15}$ According to Human Rights Watch,

\footnotetext{
${ }^{11}$ In calling China a 'strategic competitor', the United States is therefore identifying itself as China's strategic competitor and has not indicated otherwise. See Mattis, Jim, 'Summary of the 2018 The National Defense Strategy of the United States of America: Sharpening the American Military's Competitive Edge', p. 1. Retrieved from https://www.defense.gov/Portals/1/Documents/pubs/2018-National-Defense-StrategySummary.pdf.

${ }^{12}$ Information Office of the State Council of the PRC, “East Turkistan" Terrorist Forces Cannot Get Away with Impunity', 21 January 2002, Section 2. Retrieved from http://www.china.org.cn/english/2002/Jan/25582.htm ${ }^{13}$ Aljazeera, Interactive: China's Uighur Unrest - Timeline of Ethnic Violence. Retrieved from http://www.aljazeera.com/indepth/interactive/2014/09/interactive-china-uighur-unrest201492282424478793.html; 'Kunming Train Station Attack Leaves Dozens Dead', Associated Press, 1 March 2014. Retrieved from http://www.cbc.ca/news/world/kunming-train-station-attack-leaves-dozens-dead1.2556302

${ }^{14}$ Zhou, Zunyou, 'Chinese Strategy for De-radicalization', Terrorism and Political Violence 30 (2018) (published online: 9 June 2017, https://doi.org/10.1080/09546553.2017.1330199).

15 'Self-immolations by Tibetans', International campaign for Tibet, last updated 7 March 2018. Retrieved from https://www.savetibet.org/resources/fact-sheets/self-immolations-by-tibetans/
} 
four had done so in 2017. Yet Tibetans who set themselves alight are considered to be a terrorist threat to the Chinese state. This shows the deep psychological relationship between the state, which believes in thought reform, and its dissenters who seek to protest through death.

Besides cultural and religious controls, environmental degradation and economic domination by Han Chinese have contributed to ethnic unrest in both regions. With Han Chinese having been encouraged to settle in Xinjiang, the Uyghurs are no longer the majority of Xinjiang's population of 22 million but account for $45 \%$. In recognition of the need to address development as a way of ameliorating discontent, President Xi Jinping called for "poverty alleviation policies and taking the poor areas in southern Xinjiang as the main battlefield in poverty relief' at the 12 th National People's Congress in $2017 .{ }^{16}$ Tibet, with a population of only 3.2 million, has had half a million people lifted out of poverty in the five years to 2018 ; and government projects (especially infrastructure) are expected to reduce the poverty rate even further under a nationwide policy to end extreme poverty by $2020 .{ }^{17}$ Thus economic gains are pitted against cultural losses when it comes to counter-terrorism 'with Chinese characteristics'. The environment, too, has been given a higher profile in government policy, with numerous programs underway. In his report to the 19th National Congress of CCP in 2017, General Secretary Xi Jinping has sought to implement "the strictest possible systems for environmental protection" and develop "eco-friendly growth models and ways of life". ${ }^{18}$ The environment has become as high profile as anti-corruption in Xi's China, with both seen as sources for dissatisfaction across Chinese society and not only its ethnic minorities who seek to preserve their homelands.

\section{'The Three Evils'}

For China, 'terrorism' is commonly found in the company of 'separatism' and 'religious extremism' (referring to jihadism and radical Islam), which as the government slogan states, constitute the 'three evils' but which is also constituted by them. Thus a 'terrorist' in China is likely to be a separatist and religious extremist. Separatists and religious extremists, in the Chinese perspective, are terrorists.

Still, there are degrees of difference. Ethnic unrest need not equate with terrorism. Apart from some terrorist activity within China, political dissenters are not terrorists. As Zambelis observes with regard to the Turkic Muslims, the "radical Islamist strain . . . constitutes a

\footnotetext{
${ }^{16}$ Xinhua, 'Xi Calls for Building “Great Wall of Iron” for Xinjiang's Stability', Xinhuanet, 10 March 2017. Retrieved from http://www.xinhuanet.com/english/2017-03/10/c_136119256.htm

${ }^{17}$ Xinhua, 'Tibet Lifts 530,000 People Out of Poverty in 5 Yrs', Xinhuanet, 2 March 2018. Retrieved from http://www.xinhuanet.com/english/2018-03/02/c_137011082.htm

${ }^{18}$ Xi Jinping, 'Secure a Decisive Victory in Building a Moderately Prosperous Society in All Respects and Strive for the Great Success of Socialism with Chinese Characteristics for a New Era', Report to the 19th National Congress of the Communist Party of China, 18 October 2017, p. 20. Retrieved from news.xinhuanet.com/english/special/2017-11/03/c_136725942.htm
} 
fringe among Uighur militants". ${ }^{19}$ However, since 9/11 China has re-framed its secessionist problems as terrorism:

In Xinjiang, such framing has helped justify the development of a well-documented, hightech "security state" to ensure the "comprehensive supervision" of the region. This has occurred in parallel with an intensification of efforts to regulate and control Uyghur religious and cultural practice, and heightened rhetoric of a "people's war" against "Uyghur terrorists". ${ }^{20}$

Fighting the 'three evils' of terrorism, separatism and religious extremism extends to China's foreign security policy in the form of the Shanghai Cooperation Organisation (SCO), headquartered in Beijing. It began as the Shanghai Five, comprising China, Russia, Kazakhstan, Kyrgyzstan and Tajikistan as a multilateral means of demilitarising the former Soviet border and creating areas of cooperation. The Shanghai Five became the 21 st century SCO with the addition of Uzbekistan. After India and Pakistan joined, SCO's geographic coverage and population made it the world's largest regional organisation. ${ }^{21}$ When coupled with the megaproject of BRI, China's influence beyond its borders may be viewed as the creation of strategic theatres in which threats to the Chinese state are ameliorated and opportunities expanded. Indeed, SCO has become a limited kind of 'NATO' in which counter-terrorism and non-traditional security threats constitute its mission lifeblood. SCO's Regional Anti-Terrorist Structure (RATS) in Uzbekistan lies at the heart of Central Asia. According to Li Wei, an anti-terrorism specialist at the China Institutes of Contemporary International Relations:

China is keen to counter terrorism not just because of its global belt and road projects, but because no country can deal with these threats through domestic policies alone. China has a special role in this because those projects will help to bring economic development to other countries, and this could effectively help to combat terrorism. Development and regional stability are of course interrelated. ${ }^{22}$

The other side of the coin is that the Belt and Road projects provide easier targets for terrorists than within China. This would include the $\$ 62$ billion China-Pakistan Economic Corridor (CPEC), which runs through lawless territory in Pakistan. Moreover, Pakistan's North Waziristan is reported to host ETIM bases with hundreds of Uyghur militants. ${ }^{23}$ Chinese private security companies (PSC) are one solution for protecting lives and BRI projects abroad. In 2017 there were some 5,000 PSCs employing 4.3 million personnel

\footnotetext{
${ }^{19}$ Zambelis, Chris, 'Uighur Dissent and Militancy in China's Xinjiang Province', CTC Sentinel 3, 1 (January 2010), p. 17.

${ }^{20}$ Clarke, Michael, 'Xinjiang's “Transformation Through Education” Camps', The Interpreter, 25 May 2018. Retrieved from https://www.lowyinstitute.org/the-interpreter/xinjiangs-transformation-through-education-camps 21 'The Evolution of the Shanghai Cooperation Organisation', IISS Strategic Comment 24, 19 (June 2018).

${ }^{22}$ Quoted in Wu, Wendy and Kinling Lo, 'China Calls on Region to Work Together to Fight Terror Threats Ahead of Security Summit', South China Morning Post, 8 June 2018. Retrieved from https://www.scmp.com/news/china/diplomacy-defence/article/2149979/china-calls-region-work-together-fightterror-threats

${ }^{23}$ Ramachandran, Sudha, 'Chinese Projects in Pakistan Prove Tempting Targets for Terrorist Groups', China Brief 16, 3 (8 February 2018). Retrieved from https://jamestown.org/program/chinese-projects-pakistan-provetempting-targets-terrorist-groups/
} 
(mostly former People's Liberation Army and police officers) in China, and of these around 20 (totalling 3,200 personnel) functioned internationally. ${ }^{24}$ The 'Regulation on the Administration of Security and Guarding Services' law of 2009 covers the private security sector in China, though their control by the Ministry of Public Security and the nature of their tasks that include providing security for state-owned companies, hardly makes them 'private'. However, the 20 Chinese PSCs operating abroad are not covered by domestic regulations. Instead, the 'Regulation on the Safety Management of Overseas Chinese-Funded Companies, Institutions and Personnel', issued by the Ministry of Commerce in 2010, devolves responsibility to the Chinese firms that employ them. In an unregulated environment outside of China, PSCs could theoretically become 'private'. ${ }^{25}$ This may be seen as a two-edged sword: Chinese PSCs through their actions could bring disrepute to China which prides itself on not interfering in the affairs of other sovereign states; on the other hand, PSCs could be trained to be used for activities which are best avoided by the People's Liberation Army. This could be on an ad hoc basis, somewhat like the use of China's maritime militia of 'fishermen' to advance maritime claims - albeit the structure of the militia is different as it ultimately reports to the Central Military Commission. Nonetheless, under the policy of civil-military integration this would not be difficult to envisage, especially in the cause of protecting BRI assets from terrorist sabotage.

When it comes to Syria, though, China has supported the Assad government with its own special forces. Deployment overseas on counter-terrorism missions is allowed under a law adopted in 2015. In 2017, a unit from the People's Liberation Army special operations forces known as the Night Tigers was deployed to Syria, and since 2016 Chinese military forces have been in Syria training Assad's forces on "Chinese-made weapons, intelligence gathering, logistics, and field medicine". ${ }^{26}$

China's concern is that militant separatists have become jihadists as a result of fighting in Syria. The Turkestan Islamic Party (TIP) with "several thousand Chinese Uighur members" is affiliated to al-Qaeda. In 2014, when Islamic State threatened China for oppressing the Uyghurs, about 300 Uyghur militants are thought to have joined IS in Syria. This number increased to about 5,000 - "most were fighting 'under their own banner' to promote their separatist cause". ${ }^{27}$ The jihadist militias they joined included the Jabhat al-Nusra Front, Hayaat Tahrir el-Sham, and IS. ${ }^{28}$ Islamic State claimed responsibility for the killing of a Chinese hostage in 2015. In 2016 a suicide bombing of the Chinese embassy in the Kyrgyz

\footnotetext{
${ }^{24}$ Nouwen, Meia, and Legarda, Helena, 'Guardians of the Belt and Road', China Monitor, MERICS and IISS, pp. 4,5 .

${ }^{25}$ See discussion in Nouwen \& Legarda, ibid.

${ }^{26}$ Neriah, 'Chinese Troops Arrive in Syria to Fight Uyghur Rebels'; 'China to Deploy "Night Tigers" to Syria in Support of Assad's Forces', The Arab News, 29 November 2017. Retrieved from https://www.alaraby.co.uk/english/news/2017/11/29/china-to-deploy-night-tigers-to-syria

${ }^{27}$ According to the Syrian ambassador to China, Imad Moustapha, quoted in Blanchard, Ben, 'Syria Says up to 5,000 Chinese Uighurs Fighting in Militant Groups', Reuters, 11 May 2017. Retrieved from https://www.reuters.com/article/uk-mideast-crisis-syria-china/syria-says-up-to-5000-chinese-uighurs-fightingin-militant-groups-idUSKBN1840UP

${ }^{28}$ Neriah, Jacques, 'Chinese Troops Arrive in Syria to Fight Uyghur Rebels', Jerusalem Center for Public Affairs, 20 Decemeber 2017. Retrieved from http://jcpa.org/chinese-troops-arrive-syria-fight-uyghurrebels/\#_edn4
} 
capital of Bishkek was ordered by Uyghur terrorist groups active in Syria and financed by alQaeda's Nusra Front. In 2017, IS released a half-hour video which showed Uyghur IS militants threatening "to shed blood like rivers" to "avenge the oppressed" in Xinjiang. ${ }^{29}$ (Three Chinese nationals were subsequently killed in Pakistan - two were teachers in Baluchistan province and one was working for a shipping firm in Karachi.) President Xi Jinping called for a "great wall of iron" to prevent the extremists entering China. ${ }^{30}$ Restrictions, imported from Tibet via Chen Quanguo, Tibet's and later Xinjiang's Communist Party leader, were already in place. Since his arrival in Xinjiang in 2016, internal security forces grew even heavier, foreign travel (including the Haj) was banned, long beards were prohibited as were veils for women.

By 2018, Islamic State had become a fraction of its former status of 100,000 fighters, having been largely pushed out of Iraq and Syria. A UN report by sanctions monitors reported that between 20,000 and 30,000 remained in Iraq and Syria and that among these "many thousands" were foreign fighters. ${ }^{31}$ An estimated 3,500 to 4,000 had relocated to Afghanistan, and Central Asian states were concerned that the threat was growing. ${ }^{32}$ Xinjiang borders Afghanistan along the narrow Wakhjir Corridor. It can potentially be used by Chinese forces in counter-terrorism operations in Afghanistan. In the past it had been considered as an alternative route for supplying US and NATO forces fighting the Taliban, but China was not prepared to allow this to happen on its sovereign territory. ${ }^{33}$

\section{Security from Within}

$\mathrm{Xi}$ Jinping's "great wall of iron" is manned by four security forces that are responsible for dealing with terrorism in China: the Ministry of Public Security (MPS), the Ministry of State Security (MSC), the People's Armed Police (PAP), and the People's Liberation Army (PLA). Their main functions can be summarised as maintenance of public order by the MPS, protection of state secrets and counter-intelligence work by the MSC, internal paramilitary responsibilities by the PAP, and external defence by the PLA. The PLA is included as an internal security force in view of its role in protecting the Chinese Communist Party leadership. In effect, it is the "armed wing of the CCP" and "the ultimate guarantor of the CCP's rule". ${ }^{34}$ The National Security Law of 2015 and the Counter Terror Law of 2016 provide the legal framework for "new crimes of terrorism" against state security.

\footnotetext{
${ }^{29}$ The US-based SITE Intelligence Group, cited in Carlson, Benjamin, 'Bloody Islamic State Video puts China in Crosshairs', The Times of Israel, 1 March 2017. Retrieved from https://www.timesofisrael.com/bloodyislamic-state-video-puts-china-in-cross-hairs/

${ }^{30}$ Xinhua, 'Xi Calls for Building "Great Wall of Iron” for Xinjiang's Stability', Xinhuanet, 10 March 2017.

Retrieved from http://www.xinhuanet.com/english/2017-03/10/c_136119256.htm

${ }^{31}$ Analytical Support and Sanctions Monitoring Team, 22nd Report to UN Security Council, 27 July 2018 , p. 5.

32 Ibid., p. 16.

33 'China Mulls Afghan Border Request', $B B C$ News, 12 June 2009. Retrieved from http://news.bbc.co.uk/2/hi/south_asia/8097933.stm

${ }^{34}$ Office of the Secretary of Defence, Military and Security Developments Involving the People's Republic of China 2018 (Arlington, VA: Department of Defence, 16 May 2018), p. 48. The role of each of the four internal security forces is summarised here.
} 
Of the four security forces, the most prominent is People's Armed Police. The Law on the People's Armed Police Force (2009) mandates the mobilisation of the force to deal with riots, crimes and emergencies. In general, it is expected that the PAP would play a primary role in internal security and the PLA a secondary role (unlike 'Tiananmen Square Massacre' when PLA played a primary role).

Conservatively estimated at 660,000 strong, ${ }^{35}$ the PAP is responsible for internal security and domestic stability. It comes under the authority of the Central Military Commission (CMC), though prior to 2017 it was under the dual command of the CMC and the State Council. Its removal from civilian control strengthens the CMC's role in China's security and hence party control over the armed forces. It also prevents PAP's appropriation by civil authorities at the regional level that potentially may challenge the central government. Also, in a further separation of the civilian and military elements of PAP, in March 2018 China announced the "withdrawal of civilian-oriented, firefighting and frontier defense troops from the People's Armed Police Force" 36 that would be transferred to state institutions such as those responsible for public security and emergency response. So not only has PAP been placed solely under military command but its civilian components have been divested. One of the difficulties inherent in this separation is that PAP may not be as responsive and adaptable to local conditions as it once was. This is because PAP has hitherto been active in policing tasks. Moreover, the removal of civilian tasks represents a counter-trend to China's civilmilitary integration policy. The PAP is an exception in that it is even more directly responsible for the survival of the CCP from internal threats than the more externally-focused PLA. The Party knows where the most serious threats lie and budget allocations support this.

In the 2010s, PAP's budget was consistently more than the official budget for the PLA. A detailed comparison of external defence and internal security budgets by Zenz shows that in 2016 external defence spending rose by $7.5 \%$ while domestic security spending increased by $17.6 \% .{ }^{37}$ Not surprisingly regions with restive minorities have higher security budgets than less restive regions.

While domestic security spending across all provinces and regions rose by 215 percent between 2007 and 2016, Xinjiang's grew by 411 percent, the TAR's [Tibet Autonomous Region] by 404 percent, and Qinghai Province's by 316 percent (Qinghai's population is 25 percent Tibetan). Spending in Sichuan Province increased by 234 percent, but spending in Sichuan's two Tibetan Autonomous Prefectures, Ganzi and Aba, which have seen numerous self-immolations since 2008, grew by 295 percent.

\section{Impact on Chinese Society}

\footnotetext{
35 The International Institute for Strategic Studies (IISS), The Military Balance 2018, Routledge, 2018, p. 258.

${ }^{36}$ Deng, Xiaoci, 'Civilian-oriented Troops Withdrawn from Armed Police Force, Enhancing CPC Management', Global Times, 21 March 2018. Retrieved from http://www.globaltimes.cn/content/1094618.shtml

${ }^{37}$ Zenz, Adrian, 'China's Domestic Security Spending: An Analysis of Available Data', China Brief 18, 4 (12 March 2018). Retrieved from https://jamestown.org/program/chinas-domestic-security-spending-analysisavailable-data/
} 
The Chinese government's attempt to deal with terrorism in its Western regions has fuelled Islamophobia amongst Han Chinese. The government has not attempted to control or correct negative stereotyping of Muslims by the media, ${ }^{38}$ which it should be able to do in view of strict censorship controls in the country. Ethnic relations are likely to suffer further in such a media atmosphere. This contradicts President Xi Jinping's desire for "ethnic unity and cultural diversity". ${ }^{39}$ Ethnic disunity could lead to domestic conflict that would undermine the very 'stability' upon which the CCP depends for its survival.

On the other hand, citizen education campaigns have also flourished. Similar to the ideological mobilisation of the Cultural Revolution (which also had the re-education through labour camps), everyone is expected to take responsibility for China's security in the current era. Article 11 of the 2015 State Security Law states: “All citizens of the People's Republic of China, state authorities, armed forces, political parties, people's groups, enterprises, public institutions, and other social organizations shall have the responsibility and obligation to maintain national security. $" 40$ A national security education day (April 15) was introduced by this new law. A state security education campaign across schools and in the wider media included a warning against sharing state secrets with foreigners. ${ }^{41}$

\section{The Losing of Hearts and Minds}

For all China's high-tech embrace of counter-terrorism methods, those it regards as terrorists employ low-tech methods: knives, needles, car bombs, self-immolation. Low-tech, as the West has found, is difficult to control, but the use of security barriers and surveillance technology has had a containment effect. Moreover, the goals of the 'terrorists' have not been fulfilled. The Chinese state remains in firm control of both Xinjiang and Tibet. However, the blowback effect, especially as China can be targeted through its transregional infrastructure projects and citizens working abroad cannot be underestimated. Beijing's expectation that current harsh measures are only a phase and justified for the sake of a change in mentality may be over-optimistic, just as the argument that development will bring with it stability rather than greater awareness - and demands - for rights. Unless the prevailing leadership takes a leaf out of Chairman Mao's book, and seeks to win hearts and minds, counterterrorism with Chinese characteristics will look increasingly like another long war without resolution.

\footnotetext{
${ }^{38}$ Luqiu, Luwei Rose and Fan Yang, 'Islamophobia in China: news coverage, stereotypes, and Chinese Muslims' perceptions of themselves and Islam', Asian Journal of Communication, published online: 28 Mar 2018, https://doi.org/10.1080/01292986.2018.1457063

${ }^{39}$ Inkster, Nigel, 'Chinese Culture and Soft Power', IISS Analysis, 27 March 2018. Retrieved from https://www.iiss.org/blogs/analysis/2018/03/chinese-culture-soft-power

${ }^{40}$ Ministry of National Defence, PRC, National Security Law of the People's Republic of China (2015).

Retrieved from http://eng.mod.gov.cn/publications/2017-03/03/content_4774229.htm

${ }^{41}$ See Hoffman, Samantha, “'Dangerous Love”: China's All-Encompassing Security Vision', National Interest. 17 May 2017. Retrieved from https://nationalinterest.org/feature/dangerous-love-chinas-all-encompassingsecurity-vision-16239
} 